San Jose State University

SJSU ScholarWorks

Master's Theses

Master's Theses and Graduate Research

1989

\title{
Effectiveness of an AIDS and universal infection control precautions program for certified nursing assistants
}

M. H. Reuss von Plauen

San Jose State University

Follow this and additional works at: https://scholarworks.sjsu.edu/etd_theses

\section{Recommended Citation}

Reuss von Plauen, M. H., "Effectiveness of an AIDS and universal infection control precautions program for certified nursing assistants" (1989). Master's Theses. 3107.

DOI: https://doi.org/10.31979/etd.zm9r-3vtq

https://scholarworks.sjsu.edu/etd_theses/3107

This Thesis is brought to you for free and open access by the Master's Theses and Graduate Research at SJSU ScholarWorks. It has been accepted for inclusion in Master's Theses by an authorized administrator of SJSU ScholarWorks. For more information, please contact scholarworks@sjsu.edu. 


\section{INFORMATION TO USERS}

The most advanced technology has been used to photograph and reproduce this manuscript from the microfilm master. UMI films the text directly from the original or copy submitted. Thus, some thesis and dissertation copies are in typewriter face, while others may be from any type of computer printer.

The quality of this reproduction is dependent upon the quality of the copy submitt.eu. Broken or indistinct print, colored or poor quality illustrations and photographs, print bleedthrough, substandard margins, and improper alignment can adversely affect reproduction.

In the unlikely event that the author did not send UMI a complete manuscript and there are missing pages, these will be noted. Also, if unauthorized copyright material had to be removed, a note will indicate the deletion.

Oversize materials (e.g., maps, drawings, charts) are reproduced by sectioning the original, beginning at the upper left-hand corner and continuing from left to right in equal sections with small overlaps. Each original is also photographed in one exposure and is included in reduced form at the back of the book. These are also available as one exposure on a standard $35 \mathrm{~mm}$ slide or as a $17^{\prime \prime} \times 23^{\prime \prime}$ black and white photographic print for an additional charge.

Photographs included in the original manuscript have been reproduced xerographically in this copy. Higher quality $6^{\prime \prime} \times 9^{\prime \prime}$ black and white photographic prints are available for any photographs or illustrations appearing in this copy for an additional charge. Contact UMI directly to order.

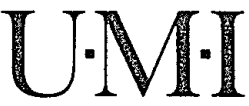



Order Number 1337841

Effectiveness of an AIDS and universal infection control precautions program for certified nursing assistants

Reuss von Plauen, Michael Heinrich, M.S.

San Jose State University, 1989 



\title{
Effectiveness of an AIDS and Universal Infection Control Precautions Program for Certified Nursing Assistants
}

\author{
A Thesis \\ Presented to \\ The Faculty of the Department of Nursing \\ San Jose State University
}

In Partial Fulfillment

of the Requirements for the Degree

Master of Science

By

M. H. Reuss von Plauen

August, 1989 


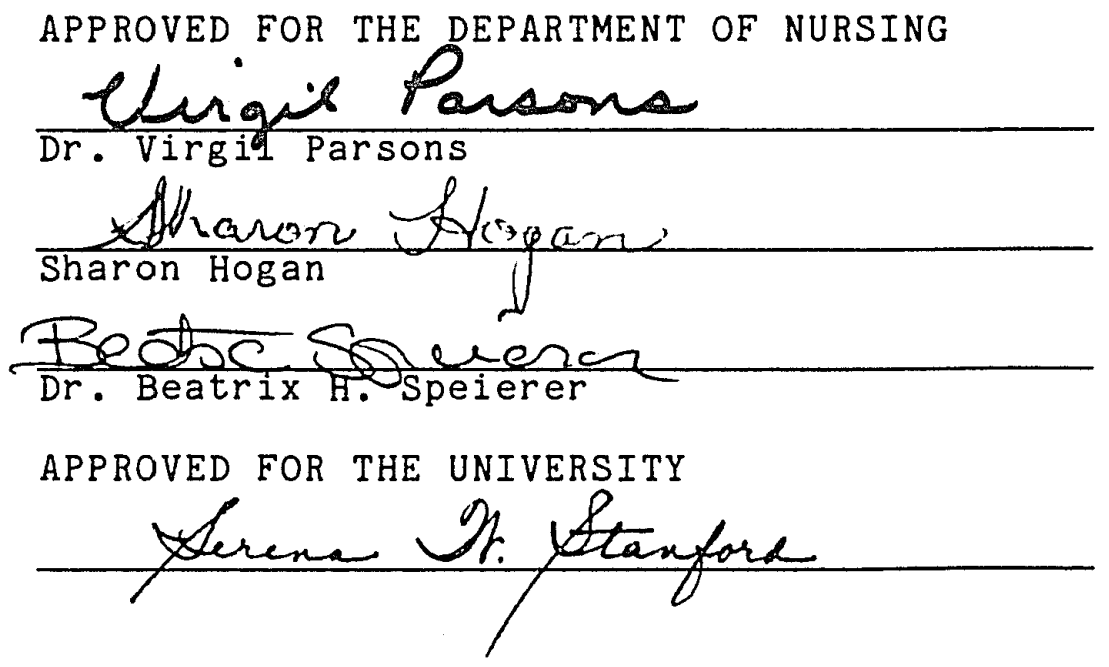




\section{ACKNOWLEDGEMENTS}

To:

Dr. Beatrix H. Speierer

Her Serene Highness, The Princess Beatrix II Reuss von Plauen

(died: 11 March 1989)

Dr. Virgil Parsons

Sharon Hogan (faculty)

Dr. Marcia Canton (faculty) 


\section{ABSTRACT}

EFFECTIVENESS OF AN AIDS AND UNIVERSAL INFECTION CONTROL PRECAUTIONS PROGRAM FOR CERTIFIED NURSING ASSISTANTS

by M. H. Reuss von Plauen

This thesis addressed the effectiveness of an inservice program on AIDS and universal precautions of infection control for Certified Nursing Assistants (CNAs). The program was designed to promote the health and safety of the CNAs' patients with AIDS or with HIV+ diagnosis within a skilled nursing facility. The knowledge of the proper use of universal precautions would assist the CNAs in improving the quality of care for their patients and reduce their fear of the AIDS disease.

Research on this subject reveals that very few inservice education materials have been geared to the understanding of the CNAs, the primary health care providers for the elderly patients within the skilled nursing facility setting. An increase in the CNAs' knowledge of the AIDS disease and the proper use of universal, infection control precautions were tested in a pretest and a posttest. The posttest scores showed a significant increase in the CNAs' knowledge. 
TABLE OF CONTENTS

Page

LIST OF TABLES • • • • • • . • • • • • • • • • vii

LIST OF FIGURES • • • • • . . • . • • • . . . . • viii

Chapter

1. INTRODUCTION • • . . . . . . . . . . . . . . . 1

Problem, Purpose, and Need . . . . . . . . . . 2

Research Question and Hypothesis . . . . . . . 3

Setting and Sample . . . . . . . . . . . . . 4

Definition of Terms . . . . . . . . . . . . 5

Research Design . . . . . . . . . . . . . 6

Scope and Limitations . . . . . . . . . . . . 7

2. CONCEPTUAL FRAMEWORK AND RELATED IITERATURE

Conceptual Framework . . . . . . . . . . . . . . 9

Related Iiterature . . . . . . . . . . . . 16

3. METHODOLOGY . . . . . . . . . . . . . . . . . 23

Research Design . . . . . . . . . . . . . 23

Instrument . . . . . . . . . . . . . . . . 24

Setting and Sample . . . . . . . . . . . . 24

Data Collection and Analysis . . . . . . . . . 27

4. FINDINGS . . . . . . . . . . . . . . . . . 29

Characteristics of the Sample . . . . . . . . . 29

Analysis of the Test Scores . . . . . . . . . 32

5. SUMMARY, CONCLUSIONS, AND RECOMMENDATIONS . • • . . 37

Summary • • • • . . . . . . . . . . . . . 37 
5. SUMMARY, CONCLUSIONS, AND RECOMMENDATIONS (cont'd) Conclusions . . . . . . . . . . . . . . 38 REFERENCES . . . . . . . . . . . . . . . . . . 40 APPENDIXES . . . . . . . . . . . . . . . . . . . 44

A. Consent Letters . . . . . . . . . . . . . . 44

B. Outline of Presentation . . . . . . . . . 52

C. Pretest and Posttest . . . . . . . . . . 55

D. Demographic Information . . . . . . . . . 61

E. Educational Requirements . . . . . . . . . 64 


\section{IIST OF TABLES}

Table Page

1. Demographic Comparison of Experimental and Control Groups . . . . . . . . . . . . . . . 30

2. Comparison of Pretest Mean Scores Between the Experimental and Control Groups . . . . . . . 33

3. Comparison of Pretest and Posttest Scores Within the Experimental and Control Groups . . . . . . . 35

4. Comparison of Posttest Mean Scores within the Experimental and Control Groups . . . . . . . 35 


\section{LIST OF FIGURES}

Figure

Page

1. Conceptual Framework for Curriculum/Inservice

$$
\text { Program . . . . . . . . . . . . . . . . } 10
$$

2. Conceptual Framework for the AIDS and

$$
\text { Universal Precautions Inservice Program . . . . } 11
$$

3. Nonrandomized Control Group Pretest/Posttest

Design . . . . . . . . . . . . . . . . 25 


\section{Chapter 1}

\section{INTRODUCTION}

The fear of Acquired Immune Deficiency Syndrome (AIDS) and of patients with Human Immunodeficiency Virus Positive (HIV+) reactions has created unnecessary panic among health care workers. Health care workers have their own fears and misconceptions on which to base decisions about caring for persons with AIDS (PWA) (Schietinger \& McCarthy, 1988, p. 277). Although it is known that AIDS is transmitted only by blood and body fluids, many health care providers remain fearful, particularly of passing contamination on to family and friends. Hatfield and Dunkel (1988) found the "fear of contagion may accelerate into panic; the fear of death and the dying person--as if death, too, might be transmissible is not uncommon among nursing personnel" (p. 262).

AIDS is one of the potentially serious health problems facing the elderly who received blood transfusions prior to the 1985 development of the HIV blood test (Tufft, 1987). Gerontological physicians are beginning to diagnose their patients with AIDS and/or who are HIV+ in increasing numbers (Sommers, 1987). The majority of these elderly patients have been found within skilled nursing facilities (SNFs). These patients have already been compromised due to previous diseases and the aging process (Tufft, 1987) - With AIDS, these patients become more susceptible to many opportunistic 
infections which will eventually lead to death. These patients will need ongoing continual nursing care until they die. The nursing care within the SNFs is primarily provided by Certified Nursing Assistants (CNAs).

Problem, Purpose, and Need

The purpose of this study was to determine the effectiveness of an inservice program on the use of universal precautions of infection control for CNAs. The program was designed to promote the health and safety of the CNAs' patients with AIDS or HIV+ diagnosis within a SNF. The CNAs' knowledge was tested before and after the program to determine if it increased. This knowledge of the proper use of universal precautions should assist the CNAs in improving the quality of care within the SNF.

One approach to reduce the fear of catching AIDS from patients is to educate CNAs about how the proper use of universal precautions protects their own safety and the safety of all of their patients. Although diagnosing and treating medical problems are not within the scope of the practice of CNAs, the very nature of their work in SNFs makes them the personnel with whom the elderly have the most frequent contact. Thus, they are the fersons who are in the best position to identify the ongoing needs and problems of the elderly with AIDS and to bring them to the attention of the registered nurse and the physicians. Also, the 
knowledge gained by the CNAs will help to ease the fear and anxiety of the non-AIDS elderly patients.

The need for this study lies in the potential to improve the care and treatment of the AIDS and HIV+ patients, as well as to reduce the fear of a specific group of CNAs working within a SNF. Although there is no guarantee that an increase in knowledge will lead to a change in practice, this educational program should, at least, increase the CNAs' awareness of the universal infection control safeguards for themse?ves and their non-AIDS and non-HIV+ patients by using the approved precautions for all of their patients.

There is an ever increasing concern within the nursing profession to provide quality patient care. However, an expressed concern is not sufficient to change long standing routine practices and fears. Educational programs, such as this one, are necessary to provide CNAs and others with the information that they need to change their modes of interventions.

Research Question, Objectives, and Hypothesis This study addressed the question: Is there a significant increase in CNAs' knowledge about AIDS and the universal infection control precautions as compared to their knowledge before the inservice program was presented? The objectives of this study were twofold: (a) to present a 
structured inservice program on the AIDS disease process and on the universal infection control precautions to CNAs, and (b) to determine if there is an increase in their knowledge level after the administration of this program. The hypothesis to be tested was: There will be a significant increase in the CNAs' posttest scores, as compared to their pretest scores, following an inservice program on AIDS and the proper use of universal infection control precautions. Sample and Setting

The convenience sample consisted of 20 CNAs who worked in two SNFs. The course on AIDS and universal precautions was offered as one of their regularly scheduled inservice programs. While all the CNAs were required to attend these programs, the nursing assistants were given a choice as to whether or not they desired to participate in this study. The CNAs from one institution served as the experimental group $(n=10)$, while those from the other institution were the control group $(n=10)$. Though randomization of subjects was impossible, the nursing facility was randomly assigned to be the setting for either the experimental or the control group.

The setting for the study was two skilled nursing facilities located in the San Francisco area. One of the two facilities was located in an urban area, with 96 beds and a staff of 56 CNAs. This SNF was a part of a retirement 
residence owned by a nonprofit organization. The second facility was located in a suburban area, with 34 beds and a staff of 25 CNAs. The latter SNF was a for-profit corporation.

\section{Definition of Terms}

For the purpose of this study, the following definitions were used:

1. AIDS is a syndrome characterized by unusual opportunistic infections and rare malignancies in otherwise healthy indivicuals with no other reason for immune system compromise (Case Definition of AIDS, 1985).

2. Certified Nursing Assistant is a health care provider who has taken and passed a certified course of instruction approved by the California Department of Health Services, enabling her or him to perform tasks considered to be appropriate to her/his level of knowledge and under the supervision of a registered nurse or a licensed vocational nurse (Title 22, California Administrative Code, 1988, Section 72013).

3. Knowledge includes those behaviors and test situations which emphasize the remembering, either by recognition or recall, of ideas, material, or phenomena (Bloom, Engelhart, Furst, Hill \& Krathwohl, 1956, p. 62). Operationally, for this study, knowledge gain or loss is the difference between the pretest and the posttest scores. 


\section{Universal Infection Control Precautions are} infection control procedures applied to all patients based upon the risk of exposure to blood and body fluids, rather than on diagnosis, because the medical history and examination cannot reliably identify all patients infected with the HIV or other blood pathogens (Guidelines for the Prevention, 1985, p. 223).

\section{Research Design}

This research study used a quasi-experimental, two group, pretest and posttest design to test the research hypothesis (Isaac \& Michael, 1985, p. 69). The pretest and the posttest were administered to both groups; however, only group $A$, the experimental group received the teaching program on AIDS disease and the universal precautions. The other group, B, served as the control group. The control group will receive the teaching program after the study has been completed.

Each participant was assigned a code number to maintain confidentiality. This number was written on both the pretest and the posttest. Each group received identical instructions on how to complete the test and were given the same time limit. Any subject could refuse to participate or withdraw from the study without penalty. Identical questions were asked in both the pretest and posttest, 
though their sequence was varied in an effort to prevent recall.

Before the program was carried out, copies of the course outline and the test were given to a panel of three experts to help establish the content validity and readability of the test items. This panel consisted of two inservice directors and a geriatric hospital supervisor. Based upon their recommendations, revisions were made as needed.

Demographic data were collected on all participants. Statistical analysis of the data included the use of the dependent and independent $\underline{t}$ tests. The dependent $\underline{t}$ test was used to measure the differences within the groups, whereas the independent $\underline{t}$ test was used to measure differences between the two groups.

Scope and Limitations

The findings of this study were limited due to the small sample size and the inability to randomly assign the participants to either the control or the experimental group. Also, the use of the same test, both pretest and posttest treatment, could artificially raise the posttest scores due to test sensitivity. While this investigation was designed to answer the research question, perhaps the major drawback was that there was no provision for follow-up to determine if the CNAs actually implemented the 
interventions which were a part of the universal precautions. 


\section{Chapter 2}

CONCEPTUAL FRAMEWORK AND RELATED LITERATURE

Conceptual Framework

The conceptual framework for this study is based upon the Chater curriculum model (1975) which is composed of three major components of equal importance and value in the construction and implementation of a curriculum. The three components are: (a) student, (b) setting, and (c) subject. Schematically, these three components are depicted as three overlapping concentric circles indicating the interrelatedness and the relative importance of the three (Figure 1). The concepts derived from any one of the components influence the utilization of the concepts from the other two components (Bevis, 1982, p. 55).

The usefulness of the Chater model lies within its generality of application. The interrelationships of the three components and the equality of influence by these components retain the same requisite for balance whether the curriculum is a complex ongoing program or a unit of an inservice program such as the one used in this study. For this study, the students were Certified Nursing Assistants (CNAs); the setting was two skilled nursing facilities (SNFs) in the San Francisco Bay Area; and, the subject was the disease, AIDS, and the use of universal precautions as the content of an inservice program (Figure 2). 


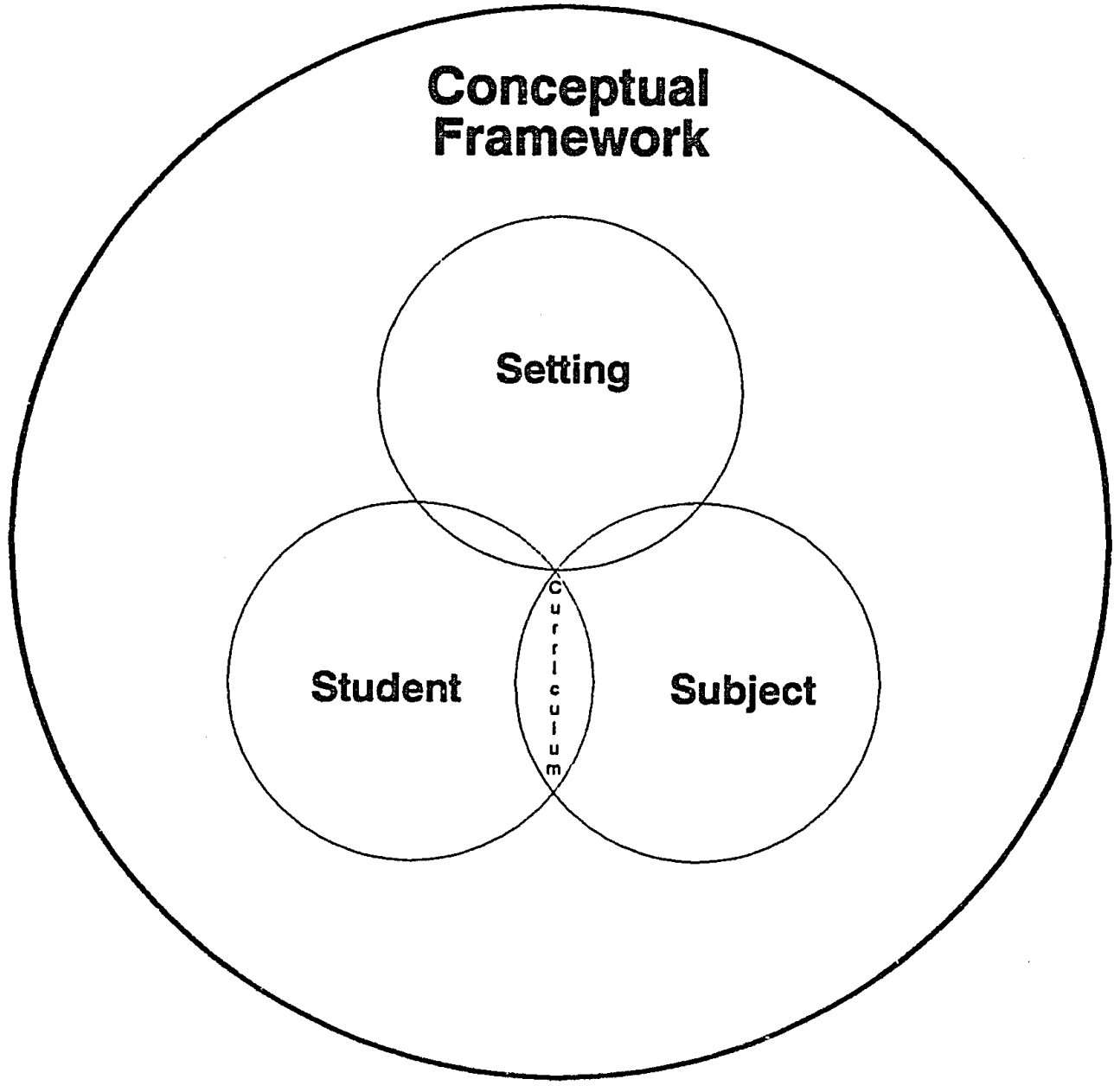

Figure 1. Conceptual Framework for Curriculum/Inservice Program.

Note. From Curriculum Building in Nursing (p. 55) by E. O. Bevis, 1982, St. Louis: Mosby. 


\section{Conceptual Framework}

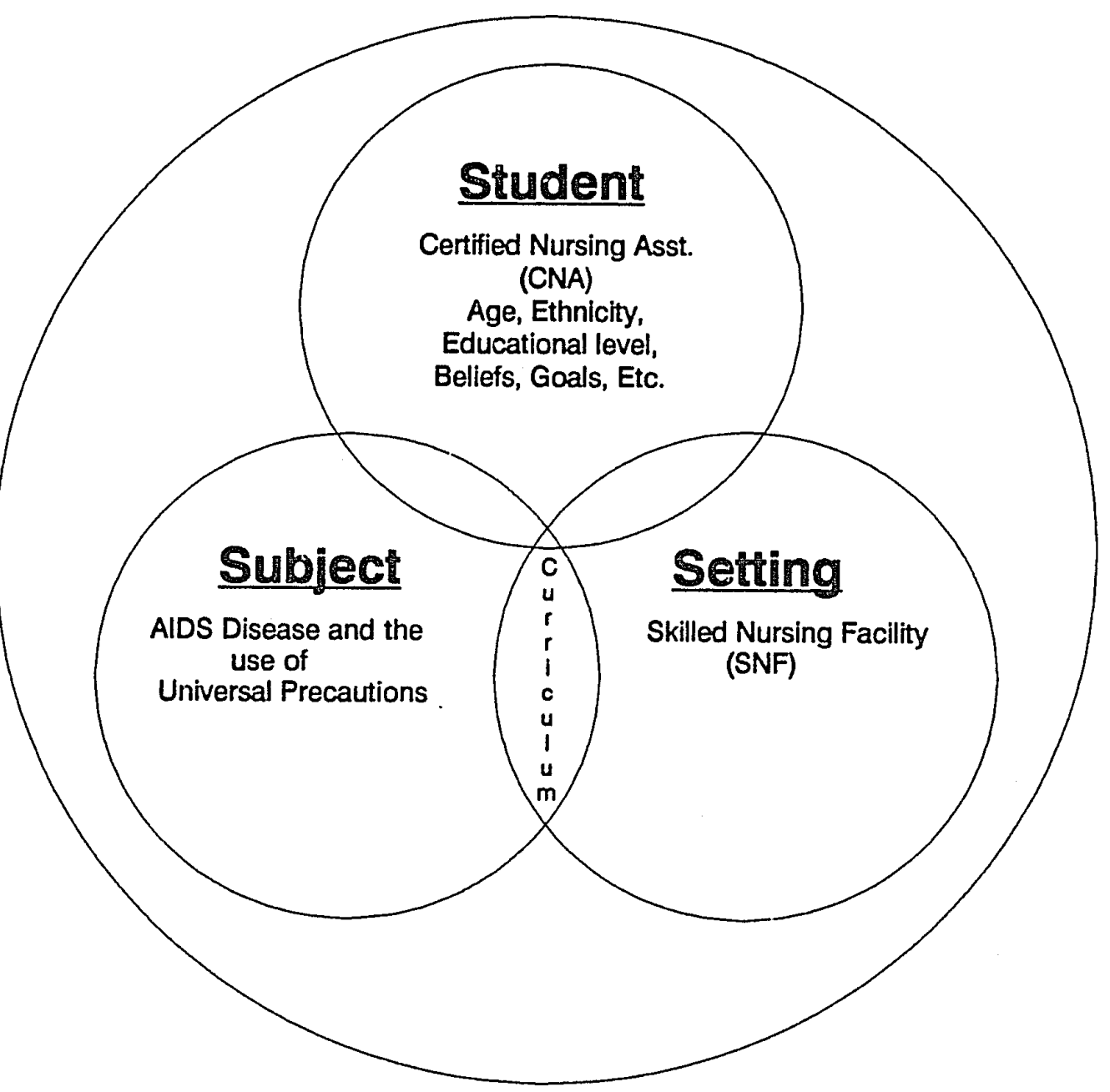

Figure 2. Conceptual Framework for the AIDS and Universal Precautions Inservice Program. Adapted from Curriculum Building in Nursing (p. 55) by E. O. Bevis, 1982, St. Louis: Mosby • 
Student

The student component consists of the characteristics of the student population. The following data must be obtained: (a) age, (b) ethnic/cultural background, (c) educational level, (d) beliefs and abilities, and (e) job requirements (including legal stipulations) (Bevis, 1982, p. 55). The characteristics of the student influence the choice of the learning theories and the teaching strategies to be implemented by the teacher.

The students in this study were CNAs who, in general, would be expected to be adult students of varied ethnic backgrounds and experiences. CNAs are required to attend inservice education programs in order to maintain their certification. Such factors necessarily influence the planning and implementing of the curriculum.

\section{Setting}

The setting component consists of the characteristics of the community and the agency in which the student's learning takes place. The community setting, the purpose of the agency, and the population served by the agency influence the structure and the function of the teaching/learning situation (Bevis, 1982, p. 55). The inservice program must reflect the needs of the community population. The approved and established policies of the agency will influence the inservice program. The setting 
for this AIDS and universal precaution inservice program included two SNFs in which care is provided for the elderly and the chronically ill client. Title 22 of the California Administrative Code defines a skilled nursing facility as a health care facility or a distinct part of a hospital which provides continuous skilled nursing care on an extended basis (Title 22, California Administrative Code, 1988, Section 72103). A skilled nursing facility provides 24-hour inpatient care and, as a minimum, includes the services of a physician, skilled nursing, dietary supervision, pharmaceutical services, and an activity program for the patients (Title 22, California Administrative Code, 1988, Section 72103).

\section{Subject}

The subject component consists of the course content, which is an important aspect since it provides the knowledge base for nursing. This subject component calls for an explicit definition of nursing as well as a conceptualization of the nursing process. Nursing is to be viewed as a decision-making process. Therefore, a specific approach is required to organize nursing knowledge and to select relevant nursing experiences (Bevis, 1982, p. 57). The subject content of the inservice program in this study was specific information regarding the AIDS disease and universal precautions. 
Title 22 of the California Administrative Code clearly defines the educational requirements for the CNA certification process and for annual inservice education upon graduation. Education programs must provide instruction in the content areas specified by Title 22 (Appendix E) . Students receive a minimum of 50 hours of classroom instruction and a minimum of 100 hours of supervised clinical practice. In addition, all CNAs are required to attend 24 documented hours of inservice education annually to maintain their certification and must have documentation of 48 hours total inservice education every 2 years in order to have their certification renewed. Title 22 dictated that each SNF must provide inservice education programs for all CNAs employed by the facility. The content must build on the basic skills and theory acquired in the Nursing Assistant Training Certification program and must include, but is not limited to, specific subjects (Appendix E).

\section{Learning Theory and Teaching Strategies}

The planning and teaching of this AIDS and universal precautions inservice program reflects the three components of the Chater curriculum model. In considering the characteristics of the students (employed adult learners), the constraints of the setting (time, cost, equipment), and the legal requirements for the subject (Appendix E), an 
eclectic use of learning theories was appropriate.

Concepts were applied from Ausabel's (1963) cognitive learning theory, Rogers' (1969) humanistic theory and Gagne's (1970) conditions of learning.

The goals of the AIDS and universal precautions inservice program were to increase the knowledge level of the CNAs working in the two SNFs and to plan for discussion and introspection to enhance the impact of the inservice program on the adult learner. The primary responsibilities of the teacher were to motivate the students and to influence the working habits, behaviors, and attitudes needed to solve problems in the clinical setting (Bevis, 1982 , p. 60).

The appropriate selection of the teaching strategies was essential in order to attract and maintain the interest of the CNAs. It was important to select relevant work-related information which could be applied readily to the students' experiences and their delivery of nursing care. The information had to assist these adult learners to increase their potential knowledge in the field of nursing by building upon their basic nursing education and to assist them in moving toward a more complex level of nursing practice (Gagne, 1970, p. 96), while, at the same time, increasing their own self-esteem (Rogers, 1969, p. 79). Since the majority of these students were likely fatigued 
after working an 8 hour shift prior to coming to this inservice, the class utilized a variety of teaching techniques to promote interest and learning in the subject area. The teaching techniques included lecture, discussion, use of the chalkboard, flip charts, outlines and "handouts." The time constraints and the size of the group dictated the lecture/discussion format of instruction. Outlines and other "handouts" reinforced the subject matter discussed in the class and provided materials for future reference. Ausabel (1968, p. 158) calls such reinforcing materials "advanced organizers." The use of discussion groups provided the individual attention necessary to lend a more humanistic approach in a structured setting (Rogers, 1969, p. 109). The small group discussions also provided the opportunity to problem solve (Gagne, 1970, p. 96).

\section{Related Iiterature}

The literature failed to disclose any studies which specifically addressed the use of an inservice program for CNAs on the AIDS disease process and implementation of universal precautions with elderly patients within SNFs. However, the literature did reveal information about AIDS and the implementation of universal infection control precautions (Bennett, 1985, p. 969; Curran, 1985, p. 3). Consequently, this literature review is centered on (a) the transmission of the HIV to elderly patients, (b) 
educational needs of the nursing staff, and (c) selected measures for the evaluation of student learning.

\section{AIDS in the Elderly}

In 1985, Jo Anne Bennett stated that $90 \%$ of the cases of transfusion-related AIDS had been traced to donations of blood made before March, 1983; fewer than 58 of the people with AIDS reported having donated blood prior to their diagnoses (p. 971). She further estimated that in 1984, only 508 of the transmission associated AIDS cases were diagnosed. AIDS is an infectious disease with potentially devastating medical and psychological consequences due to the facts that: (a) 708 of all the people die within 2 years of diagnosis; (b) 908 of all adults with AIDS are in the prime of life between the ages of 20 and 49 years; (c) infections and malignancies accompany AIDS; (d) few other diseases produce so many losses, that is loss of physical strength, mental acuity, ability to work, self-sufficiency, social roles, income and the emotional support of loved-ones; (e) treatments for AIDS-related diseases are palliative but do not cure; and (f) the public has fear of AIDS (National Institute of Mental Health, 1987, p. 1). Doctor Michael Sommers (1987), in his private practice with gerontology patients, documented that while the study of AIDS in the mainstream of the adult population is well documented, within the elderly, very little research and 
documentation exists. Further, he noted that while the incubation period for full blown AIDS in the younger population is well known to be at most 5 years, in the elderly, the incubation period is longer. The time between transfusion and the date of diagnosis suggests an incubation period of months to 7 years in the elderly. In the elderly, the nonspecific and vague early symptoms make the onset difficult to detect and many physicians fail to identify the onset or have an HIV test ordered.

KEAR radio station, in Oakland, California, in its public service announcement of November 3,1988 , stated that transfusions were the most obvious cause of AIDS within the elderly population. The radio station stated that there were over 115,000 individuals who received blood transfusions from 1978 to 1985 within the San Francisco Bay Area, who should now be tested for HIV+ status. If only 28 of this population develops AIDS, then within 5 - 7 years, 2,300 individuals will need extended nursing care.

In 1987, the last published statistics on the spread of AIDS due to blood transfusions from the Centers for Disease Control (CDC) were combined into the treatment of hemophilia/coagulation disorders. In a telephone conversation with a CDC physician (personal communication on August 1, 1988), who desired to remain anonymous, it was stated that the rationale for combining blood transfusions 
into the hemophilia classification was solely an internal decision to reduce the public concern over still obtaining AIDS through blood transfusions. While the CDC continues to downplay the possibility of acquiring AIDS through blood transfusions, the possibility still exists. The American Blood Commission, in their 1985 conference on AIDS, stated, "approximately 988 of the nation's whole blood used for transfusions is AIDS free" (p. 332). The California Morbidity Report stated in its July, 1988, publication that HIV+ antibodies were still found following the administration of Hepatitis B immune globulin. This is due to the incubation period required from the first exposure to possible detection of AIDS by the enzyme linked immunosorbul assay (ELISA).

Doctor William Tufft (1987), in his inservice education presentations to physicians and nurses, has stated that the elderly are the next wave of the AIDS epidemic. Ever increasing numbers of the elderly who had surgeries requiring blood transfusions, from 1978 onward, are beginning to manifest the early symptoms of AIDS. Educational Needs of the Nursing Staff

CNAs are the least educated of all of the nursing staff; many of them have not completed a high school education. To become a CNA, an individual must attend a 150 hour course of instruction: 50 hours of nursing theory and 
100 hours of clinical experience. Topics, such as infection control, are taught at very elemental levels. Yet, CNAs do the majority of primary nursing of the elderly patients within a SNF; they come in contact constantly with the patients' blood (open wounds) and body fluids (bowel and bladder).

According to Lose and McCarroll (1988), lack of knowledge about AIDS fosters fear (p. 340). They further state that the infection control nurse can provide the knowledge, through inservice education, to reduce this fear (Lose \& McCarroll, 1988, p. 340). Schietinger and McCarthy (1988) state that when the first patient is admitted with AIDS, leaving staff unaware that they have been caring for someone with AIDS and knowing that they did not take any special precautions can cause reactions by the nursing staff. The staff's reaction in the aftermath of its first AIDS patient is a cause for the staff to act out their ensuing panic and hysteria on the patient, whose confidentiality becomes their last concern. This staff reaction can be and should be the impetus for education. However, attempting to respond to the aroused fear and hysteria is not an effective way to impart information (p. 278).

The solution, according to Schietinger and McCarthy universal precautions prior to the admission of AIDS 
patients and to continue inservice education on a regular basis ( $p .280$ ). They also conclude that adult learning principles are the foundation for effective teaching that reduces fear and enhances knowledge within the nursing staff (p. 282 )

Fahrner (1988) states that since AIDS is a chronic life-threatening disease that has no cure, it is essentially a nursing disease. That is, the essence is caring rather than curing. While nurses are experts at providing symptom control in a supportive nurturing environment, this should be the basis of care for the acutely ill PWAs (p. 115). According to Hatfield and Dunkel (1988), the education of staff is a critical part of clinical care in the AIDS epidemic and is central to the health care professional's survival. Staff can be encouraged to adopt a philosophy of care that allows them to function effectively while meeting their patients' needs. This can be accomplished through continuing education and facilitation (p. 265).

Evaluation of Student Learning

As the AIDS epidemic continues, a systematic approach to AIDS education is necessary in every health care setting (Schietinger \& McCarthy, 1988, p. 289). They further state that a well developed training plan includes regularly (1988), is to begin inservice education about AIDS and scheduled inservice education for all staff on work time, 
and an identified AIDS resource person or persons, who are also trained facilitators. According to McNair, in his inservice in 1988, the instructor is most effective as facilitator rather than a lecturer. The role of the facilitator involves asking participants to share what they already know about AIDS and conducting learning activities that enable the participants to incorporate new information with previous knowledge. By building upon existing skills, the facilitator increases the staff's confidence in their ability to care for PWAs (McNair, 1988). Rodgers, Petermann, Oliver, DeLisser and Brown (1988) state that staff education is the important component of each educational experience which provides staff support ( $\mathrm{p}$. 314). They further state that the effectiveness of the inservice and support programs could be evaluated by the degree of participation of the nursing staff (p. 315). In summary, the literature review emphasizes that the continuing problem of AIDS in the elderly population is growing. The need for a well trained and supportive nursing staff is essential to providing quality care to the patients with AIDS or who are HIV+. An ongoing educational program with staff support systems is also necessary to provide for the needs of the nursing staff to maintain a high quality of patient care. 
Chapter 3

METHODOLOGY

The purpose of this study was to determine if a significant increase in knowledge resulted from the presentation of an inservice program on AIDS and universal infection control precautions to Certified Nursing Assistants (CNAs) working within selected skilled nursing facilities (SNFs). The hypothesis tested was: There will be a significant increase in the CNAs' posttest scores as compared to their pretest scores following an inservice program on AIDS and the use of universal infection control precautions. The independent variable was the AIDS and universal infection control precautions program; the dependent variable was the level of the knowledge as measured by the means of the scores obtained on the pretest and posttest.

\section{Research Design}

The research design was a nonrandomized two-group, pretest and posttest, quasi-experimental design (Isaac \& Michael, 1985, p. 69). Both the experimental group and the control group completed the pretest. The experimental group received the AIDS and universal precautions infection control inservice program following the pretest, while the control group did not. Both groups completed the posttest, 
after which the control group received the inservice program (Figure 3).

\section{Instrument}

An identical pretest and posttest consisting of 25 questions were designed by the researcher to measure the knowledge of the participants on AIDS and the use of universal infection control precautions (Appendix C). The test was evaluated for face validity by a panel of three experts: two inservice directors and a geriatric hospital supervisor. After suggested modifications were made, the test was given to three licensed vocational nurses in order to assess clarity and to determine the amount of time necessary for test completion. A period of 15 minutes was judged to be adequate for the test completion. The instrument designed by the researcher for collection of demographic information about the study participants was reviewed by an inservice director and a geriatric hospital supervisor (Appendix D). The research instruments (pretest/posttest and demographic information data sheet) were submitted to and approved by the San Jose State University Human Subjects Committee (Appendix A) . Setting and Sample

Two SNFs located in the San Francisco Bay Area were selected as the settings for this study. These particular facilities were chosen because the Directors of Inservice 


\begin{tabular}{l|ccc|} 
& Pretest & Treatment & Posttest \\
\cline { 2 - 4 } Experimental Group & $\mathrm{T}$ & $\mathrm{T}_{2}$ \\
Control Group & $\mathrm{T}_{1}$ & & \\
& $\mathrm{~T}_{1}$ & $\mathrm{~T}_{2}$ \\
\hline
\end{tabular}

Figure 3. Nonrandomized Control Group Pretest/Posttest Design

Note. From Handbook of Research and Evaluation (p. 69) by S. Isaac and W. B. Michael, 1985, San Diego: Edits. 
and Staff Development of both agencies were supportive of graduate student research and because of the need for this inservice program within their facilities. One of the two facilities, proprietary and located in a suburban area, had 34 skilled nursing care beds and a staff of 25 CNAs. The second facility, nonprofit and located in an urban setting, had 96 skilled nursing care beds and a staff of 56 CNAs. This latter SNF was part of a retirement residence. Both facilities cared for chronically ill patients needing 24hour skilled nursing care. The mean age of the patients was 83 years.

Each SNF provided a classroom separate from the nursing units for the presentation of the AIDS and universal infection control precautions inservice program. Each classroom was brightly illuminated, had windows and was spacious. Tables and chairs were provided for the learners. A chalkboard was available.

A total sample of 20 CNAs was derived from the staff populations of the two SNFs. Although a random selection of participants was preferable, the researcher had to rely on . voluntary participation. Because of the sample size limitations, the CNAs who volunteered from one SNF served as the experimental group, while those who volunteered from the other SNF acted as the control group. The experimental group $(n=10)$ comprised a third of the 30 CNAs employed in 
one SNF; the control group $(n=10)$ represented 208 of the 50 CNAs employed in the other SNF. The Directors of Inservice and Staff Development were contacted in both facilities and permission was obtained for the inservice program. The AIDS and universal infection control precautions inservice program was announced by the Director of Inservice and Staff Development on the monthly Inservice Education Board and before the class. The inservice programs were held at the regularly scheduled inservice times.

Data Collection and Analysis

The AIDS and universal infection control precautions inservice program (Appendix B) at each SNF was scheduled for 2:30 p.m., the regular time reserved for the CNAs' inservice programs designed to meet the annual recertification requirements. The night shift CNAs returned to the facility especially for this program, the evening shift CNAs were required to arrive 1 hour before their shift started, and the day shift CNAs attended the class at the end of their day shift. The CNAs from the evening and night shifts received overtime pay; the day shift CNAs received their regular pay.

Prior to the test administration, all CNAs were informed that their participation was voluntary. A consent form (Appendix A) was signed by all the participants, and an 
additional consent form was attached to the inservice program sign-in sheet.

In the same week, both the experimental group in one SNF and the control group in the other SNF completed the 15-minute pretest. The experimental group received the 45-minute AIDS and universal infection control precautions inservice program following the pretest, while the control group did not. The following week, both groups completed the 15-minute posttest (identical to the pretest). The control group received the entire AIDS and universal infection control precautions inservice program following the completion of the posttest.

The demographic data were analyzed by frequency and percentages. The dependent $\underline{t}$ test was used to test the significance of the differences in mean scores within the groups, whereas the independent $\underline{t}$ test was used to test for the significance of the differences in mean scores between the groups. The findings are presented in Chapter 4 in tabular and narrative form. 


\section{Chapter 4}

\section{FINDINGS}

This study addressed the question of whether there would be a significant difference in Certified Nursing Assistants' (CNAs') knowledge of AIDS and the use of universal precautions of infection control before and after receiving an inservice program dealing with these topics in the elderly. A nonrandomized, pretest-posttest, quasiexperimental design was used with knowledge operationally defined as the difference in the scores between the pretests and posttests. Two groups of CNAs from two types of skilled 'nursing facilities (SNFs) participated in this study with one group acting as the experimental group $(\underline{n}=10)$ and the other group acting as the control group $(\underline{n}=10)$. The control group did not receive the inservice program until after the posttest.

The dependent $t$ test was utilized to measure the differences within the groups, whereas the independent $t$ test was utilized to measure the differences between the two groups. The acceptable level of significance was set at p<.05. The selected demographic characteristics of the sample groups were described by frequency and percentages. - Characteristics of the Sample

Table 1 compares the experimental and control groups according to sex, age, ethnicity, education, experience, and 
Table 1

Demographic Comparison of Experimental and Control Groups

$(N=20)$.

\begin{tabular}{|c|c|c|}
\hline & Experimental $(\underline{\mathrm{n}}=10)$ & Control $(\underline{n}=10)$ \\
\hline Sex & $\underline{n}(q)$ & $\underline{n}(8)$ \\
\hline $\begin{array}{l}\mathrm{M} \\
\mathrm{F}\end{array}$ & $\begin{array}{l}1 \\
9(10)\end{array}$ & $\begin{array}{l}2(20) \\
8 \quad(80)\end{array}$ \\
\hline \multicolumn{3}{|l|}{ Age (Years) } \\
\hline $\begin{array}{l}20-30 \\
31-40 \\
41-50 \\
51-60 \\
61+\end{array}$ & $\begin{array}{ll}3 & (30) \\
5 & (50) \\
2 & (20) \\
0 & (0) \\
0 & (0)\end{array}$ & $\begin{array}{ll}2 & (20) \\
1 & (10) \\
5 & (50) \\
2 & (20) \\
0 & (0)\end{array}$ \\
\hline
\end{tabular}

Ethnicity

$\begin{array}{lll}\text { Black } & 6(60) & 8(80) \\ \text { Hispanic } & 3(30) & 2(20) \\ \text { Caucasian } & 1(10) & 0(0)\end{array}$

Education (Years)
$9-10$
$11-12$
$13+($ College $)$
$\begin{array}{ll}2 & (20) \\ 5 & (50) \\ 3 & (30)\end{array}$
$4(40)$
$6(60)$
0 (0)

CNA Experience (Years)

$2-5$
$6-10$
$11=15$
$16-20$
$21-25$

Time worked

Full Time

Part Time
4 (40)

2 (20)

$3(30)$

$\begin{array}{ll}1 & (10) \\ 0 & (0)\end{array}$

$5(50)$

0 (0)

1 (10)

2 (20)

2 (20) 
the amount of time employed. Information collected and discussed in narrative form includes marital status, parenthood, yearly income and the settings for the CNA precertification training.

Table 1 shows that the experimental and the control groups were essentially comparable, consisting predominantly of Black and Hispanic females with 9 th-12th grade educations, working full time. The groups varied somewhat in the age distribution, with 308 of the experimental group being in the 20-30 year age range, while only 208 of the control group fell into that category. Only 208 of the experimental group was in the 41-50 year age group, while 508 of the control group was in that age category. No subjects in the experimental group were in the 51-60 age group, and $20 \%$ were in the control group.

Variation in the distribution between the experimental and the control groups also existed in the number of years of experience as a CNA. Twenty percent of the experimental group had 6-10 years of experience, whereas none of the control group fitted into that experience category. Forty percent of the control group had 16-25 years of experience, while only 108 of the experimental group had that much experience.

The majority of the CNAs in both of the groups obtained their precertification education in the adult education 
programs and skilled nursing facilities ( 708 for both the experimental and the control group). The remainder attended private schools.

Yearly income ranged from $\$ 16,000-\$ 30,000$ in the experimental group, with 908 earning $\$ 16,000-\$ 20,000$ annually. In the control group, the income range was broader, with 508 earning $\$ 11,000-\$ 15,000$ annually, 108 earning $\$ 16,000-\$ 20,000$ per year, and 408 earning $\$ 21,000-$ $\$ 30,000$ annually. Data on the marital status and parenthood were incomplete and inconclusive.

\section{Analysis of the Test Scores}

The highest possible score on the pretest/posttest was 25 points. The same test was used for the pretest and posttest.

\section{Analysis of Pretest Data}

The pretest mean score of the experimental group was 17.5. The control group's pretest mean score was 20 points, 3.5 points higher than that of the experimental group. When the independent $t$ test was applied to test the difference between the pretest mean scores of the two groups, the difference was not significant $(\underline{t}(18)=2.3, \underline{p}=.55)$ at the .05 level. Therefore, the two groups were considered initially comparable as to knowledge and use of infection control principles as measured by the pretest (Table 2). 
A...........

Table 2

Comparison of Pretest Mean Scores Between the Experimental and Control Groups $(\mathrm{N}=20)$.

\begin{tabular}{lllllll}
\hline Group & $\underline{\mathrm{n}}$ & $\underline{\mathrm{M}}$ & $\underline{\mathrm{SD}}$ & $\underline{\mathrm{df}}$ & $\underline{\mathrm{t}}$ & $\underline{\mathrm{p}}$ \\
\hline Experimental & 10 & 17.5 & 3.5 & & & \\
Control & 10 & 20.0 & 2.0 & 18 & 2.3 & .55 \\
\hline
\end{tabular}




\section{Analysis of Pretest/Posttest Data}

The difference between the means of the pretest and the posttest scores of the experimental group was tested using the dependent $\underline{t}$ test. The difference was found to be highly significant $(t(9)=6.85, \underline{p}<.001)$. When the dependent $t$ test was applied to determine the difference between the control group's pretest and posttest mean scores, the difference between the control group's pretest and posttest mean scores, the difference was not significant $(\underline{t}(9)=$ $1.89, \underline{p}=.085$ ) at the .05 level. The control group's scores remained essentially the same, that is, the decrease probably occurred by chance (Table 3 ). However, the speculation could be considered that the repeated testing may have increased the control group participants' insecurity when they were confronted with answering the same questions for a second time.

Table 3 shows the experimental group increased its posttest mean score from 17.5 to 24.3 out of a possible 25 points, an increase of 6.8 points over the pretest mean score. The control group's posttest mean score was 19.16, a decrease of 0.84 below its pretest score. When the independent $\underline{t}$ was applied, the difference between the posttest scores of the two groups was found to be highly significant $(\underline{t}(18)=4.65, \underline{p}=<.001)$, as shown in Table 4. Consequently, there is evidence to support the stated 
Table 3

Comparison of Pretest and posttest Scores within the

Experimental and Control Groups $(\mathrm{N}=20)$.

\begin{tabular}{lccccccccc}
\hline \multirow{2}{*}{ Group } & \multicolumn{2}{c}{$\begin{array}{l}\text { Pretest } \\
\text { n }\end{array}$} & $\underline{M}$ & $\underline{\text { SD }}$ & $\underline{M}$ & $\underline{\text { SD }}$ & $\underline{\text { df }}$ & $\underline{t}$ & $\underline{P}$ \\
\hline Experimental & 10 & 17.5 & 3.5 & 24.3 & 1.2 & 9 & 6.85 & $<.001$ \\
Control & 10 & 20.0 & 2.0 & 19.16 & 3.3 & 9 & 1.89 & .085 \\
\hline
\end{tabular}

Table 4

Comparison of Posttest Mean Scores Between the Experimental and Control Groups $(N=20)$.

\begin{tabular}{lllllll}
\hline Group & $\underline{\mathrm{n}}$ & $\underline{\mathrm{M}}$ & $\underline{\mathrm{SD}}$ & $\underline{\mathrm{df}}$ & $\underline{\mathrm{t}}$ & $\underline{\mathrm{p}}$ \\
\hline Experimental & 10 & 24.3 & 1.2 & & & \\
Control & 10 & 19.16 & 3.2 & 18 & 4.65 & $<.001$ \\
\hline
\end{tabular}


hypothesis, there will be a significant increase in the CNAs' posttest scores as compared to their pretest scores following the inservice program on AIDS and the use of universal infection control precautions. The group exposed to the experimental variable (the AIDS and universal infection control precautions program) had a significant increase in knowledge over that of the control group. 


\section{Chapter 5}

SUMMARY, CONCLUSIONS, AND RECOMMENDATIONS

AIDS and HIV+ diagnosis are increasing among the elderly patients in skilled nursing facilities (SNFs), due primarily to blood transfusions. Too often the caregivers respond in fear of catching AIDS from their patients and, therefore, do not properly utilize the appropriate infection control precautions on a consistent basis. One way to reduce this fear of AIDS is to educate Certified Nursing Assistants (CNAs), who provide the majority of primary care to the SNF patients, about the AIDS disease and the proper use of the universal infection control precautions for all the institutionalized elderly.

\section{Summary}

The purpose of this study was to determine if an increase in knowledge resulted from the presentation of an inservice program on AIDS and the use of universal infection control precautions to CNAs working in SNFs for the elderly. Knowledge gain or loss was operationally defined as the difference between the pretest and posttest mean scores of the participant groups.

Two groups of CNAs from two different SNFs ( $\underline{N}=20)$ participated in this study. A nonrandomized, two-group pretest/posttest, quasi-experimental research design was used. The dependent $\underline{t}$ test was used to test for the 
differences in mean scores within the groups, whereas the independent $t$ test was used to test the differences in mean scores between the two groups. The experimental group ( $\underline{\mathrm{n}}=$ 10) received the inservice program immediately following the pretest; the control group $(\underline{n}=10)$ did not receive the inservice program until after the posttest. A significant difference $(\underline{t}(9)=6.85, \underline{p}<.001)$ was found between the pretest and posttest mean scores of the experimental group, and a significant difference $(\underline{t}(18)=4.65, \underline{p}<.001)$ was found between the posttest mean scores of the experimental and control groups. The control group had a statistically insignificant loss between the pretest and the posttest mean scores. Consequently, the stated hypothesis was supported, that is, there would be a significant increase in the CNAs' posttest scores as compared to their pretest scores following an inservice program on AIDS and universal infection control precautions.

Conclusions and Recommendations

Generalizations from this pilot study are limited by the small size of the sample and the lack of randomization of the sample. However, the results do add credence to the requirement by the State of California that CNAs receive a specified number of inservice program hours to retain their certification (Title 22, California Administrative Code, 1988, Chapter 3). 
The significant increase in knowledge as a result of the inservice program suggests that the Chater (1975) model is applicable to the skilled nursing facility setting. It is evident that the inservice program was effective.

Based upon the findings of this study, the following recommendations are made:

1. Repeat the study using randomly selected SNFs in California.

2. When planning further studies, control for extraneous variables whenever possible, for example, the teaching strategies and the subject content.

3. Perform a follow-up study to verify if the CNAs' increase in knowledge after the inservice program produces a change in behavior, that is, by use of observations to determine whether the proper universal infection control precautions are being utilized consistently. 
REFERENCES 
References

American Blood Commission. (1985). Conference on AIDS: Transfusions associated with AIDS in the United States [Summary]. Proceedings of the American Blood Commission, 6 , 332-333.

Ausabel, D. P. (1968) - Educational psychology: A cognitive view. New York: Holt, Rinehart, \& Winston. Bennett, J. A. (1985). AIDS. American Journal of Nursing, 85, 969-972.

Bevis, E. O. (1982). Curriculum building in nursing. St. Louis: C.V. Mosby.

Bloom, B. S., Engelhart, M. D., Furst, E. J., Hill, W. H., \& Krathwohl, D. R. (1956). Taxonomy of educational objectives: The classification of educational goals. Handbook I: Cognitive domain. New York: Longmans, Green.

California Morbidity ( (1988) . HIV antibody positivity following administration of hepatitis B immune globulin (HBIG) (Infections Disease Branch \#27) Sacramento: State of California Health and Welfare Agency. Case definition of AIDS by the CDC for national reporting (CDC-Reportable AIDS) . (1985) . (Document No. 0312S). Atlanta, GA: Centers for Disease Control. Chater, S. S. (1975). A conceptual framework for curriculum development. Nursing Outlook, 23, 428-433. 
Curran, J. W. (1985). The epidemiology and prevention of AIDS (Summary). Proceedings of the International Conference on Acquired Immunodeficiency Syndrome (AIDS) (pp. 83-85). Atlanta, GA: American Journal of Nursing Corporation.

Fahrner, R. (1988) - Nursing interventions. In A. Lewis, (Ed.), Nursing care of the persons with AIDS/ARC, (pp. 115-130). Rockville, MD: -Aspen.

Gagne, R. M. (1970). The conditions of learning (2nd ed.). New York: Holt, Rinehart, \& Winston.

Guidelines for the prevention and control of nosocomial infections (CDC Recommendations). (1985) . (MMWR, Vol. 34). Atlanta, GA: Centers for Disease Control.

Hatfield, S., \& Dunkel, J. (1988). Understanding and working with the emotional reactions of staff. In A. Lewis, (Ed.), Nursing care of the persons with AIDS/ARC, (pp. 259-276). Rockville, MD: Aspen.

Isaac, S., \& Michael, W. B. (1985). Handbook in research and evaluation. San Diego, CA: Edits.

KEAR Family Radio Station. (1988). Public service announcement on blood transfusions (Radio). Oakland, CA. 
Lose, M., \& McCarroll, T. (1988). Establishment of a program to care for infants with AIDS. In A. Lewis, (Ed.), Nursing care of the persons with AIDS/ARC, (pp. 329-341). Rockville, MD: Aspen.

McNair, A. S. (1988, January) - Caring for the healthcare workers in the nursing unit. Oakland, CA: Administrative Personnel Inservice.

National Institute of Mental Health. (1987) - Coping with AIDS: Psychological and social considerations in helping people with HTIV-III infection. (Office of Scientific Information). Rockville, MD: U.S. Government Printing Office.

Opportunistic infections and kaposi's sarcoma among Haitians in the United States (CDC Recommendations). (1982). (MMWR, Vol. 31). Atlanta, GA: Centers for Disease Control.

Recommendations and prevention for transmission of infections with human T-Iymphotropy virus type III (CDC Recommendations) (1986). (MMWR, Vol. 35). Atlanta, GA: Centers for Disease Control.

Rodgers, M. S., Petermann, E. M., Oliver, P. J., Delisser, J. A., \& Brown, T. J. (1988). The approach of one community hospital. In A. Lewis, (Ed.), Nursing care of the persons with AIDS/ARC, (pp. 309-319). Rockville, MD: Aspen. 
Rogers, Carl R. (1969). Freedom to learn. Columbus, OH: Merrill.

Schietinger, H., \& McCarthy, P. (1988). Staff education: Nurses and others. In A. Lewis (Ed.), Nursing Care of the Persons with AIDS/ARC, (pp. 277-282). Rockville, MD: Aspen.

Sommers, M. J. (1987, August). Recent trends in skilled nursing facilities. Oakland, CA: Licensed Nurses Inservice.

Title 22, California administrative code (1988). Sections $72103 \& 72331$. North Highland, CA: State of California Documents Section.

Title 22, California administrative code (1988). Chapter 3. North Highland, CA: State of California Documents Section.

Tufft, R. W. (1987, September). AIDS vs. AID in the elderly patients in skilled nursing facilities. Oakland, CA: Licensed Nurses Inservice.

Universal precautions: Infection control procedures applied to all patients (CDC Recommendations) (1985) . (MMWR Vol. 34). Atlanta, GA: Centers for Disease Control. 
APPENDIX A

Consent Letters 


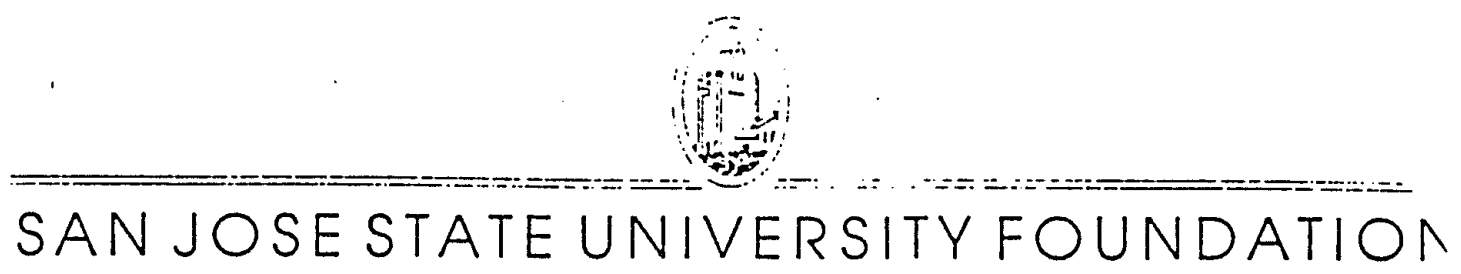

December 16,1988

M. H. Reuss von Plauen

512 Spruce Averiue

South San Francisco, CA 94080

Dear Graduate Student:

Your human subjects protocol number $\$ 7390$ has received final approval from the Human Subjects Institutional Review Board. Attached is a copy of the final approval form with the signatures of the Chairman of the Human Subjects Institutional Review Board, Dr. Robert Hyde, and the Associate Academic Vice President for Graduate Studies and Research, Dr. Serena Stanford.

Congratulations and good luck with your research!

Sincerely,

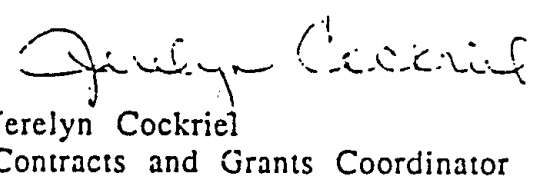

Attachment

ONE WASHINGTON SOUARE. SAN JOSE. CALIFOFNIA 95192.C139 (408) 924.1400 
SAN JOSE STATE UNIVERSITY

GRADUATE STUDIES AND RESEARCH

\section{HUMAN SUBJECTS INSTITUTIONAL REVIEW BOARD PROJECT PROPOSAL REVIEW}

1. the undersigned member of the San Jose State University Human Subjects Institutional Review Board, have reviewed the following proposal submitted to the Committee on 12/1/88 (resubmitted) by:

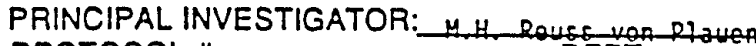

PROTOCOL \#: 7300 DEPT:

PROJECT TITLE: EFFECTIVENESS OF AN AIOS AND UMIVERSAL INEECTION

COUTROL PRECAUTIOUS PROCZAH FOR CERTIFIED IURSIHG ASSISTHITS-

I recommend the following action (indicate one):

1. Approved for clearance as irıvolving minimal risk to Human Subjects.

2. Approved for clearance with risk to Human Subjects.

3. Approved for clearance when the following conditions are met:

4. Not Approved (return to principal investigator for following reasons):

5. Expedited Review (specity condition[s] that merit expedited review):

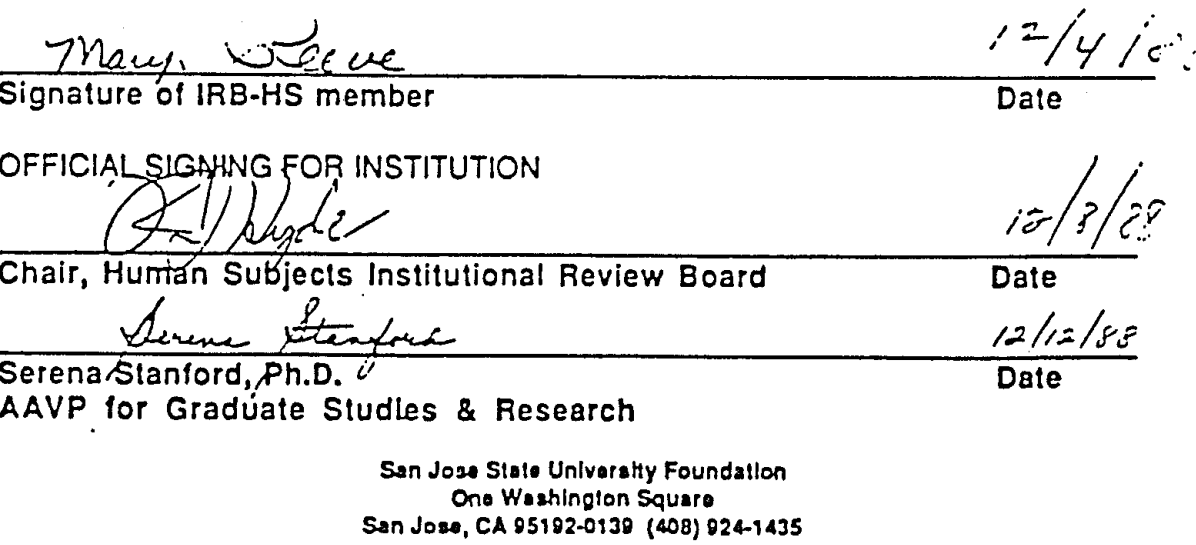


Agreement to Participate in Research San Jose State University

Responsible Investigator: M. H. Reuss von Plauen, K.N.

Title of Protocol: Effectiveness of an AIDS and Universal, Infection Control Precautions Program for Certified Nursing Assistants.

I have been asked to participate in a research study that is investigating the disease of AIDS and the use of universal, infection control precautions for certified nursing assistants. The results of this study should further our understanding of the disease of AIDS and proper use of universal, infection control precautions, and therefore, increase use of this knowledge obtained in the skilled nursing facility setting.

I understand that

1) I will be asked to participate in a pretest, an inservice program, and a posttest which should take approximately 90 minutes, during a regularly scheduled inservice.

2) There are no risks involved in this study, to the participant.

3) The possible benefit will be an increase in nursing knowledge in reference to the disease of AIDS and how to use properly the universal, infection control precautions.

4) The results from this study may be published, but any information from this study that can be identified with me will remain confidential and will be disclosed only with my permission or as required by law.

5) Any questions about my participation in this study will be answered by M. H. Reuss von Plauen, R.N., whose telephone number is (415) 742-9720. Complaints about the procedures may be presented to $\mathrm{Dr}$. Virgil Parsons, Department Chairman of the Nursing Department, whose telephone number is (408) 924-3182. For questions or complaints about the research subject's rights, or in the event of research-related injury, contact Dr. Serena Stanford, the Associate Academic Vice President for Graduate Studies \& Research, whose telephone number is (408) 924-2480. 
6) My consent is given voluntarily without being coerced. I may refuse to participate in this study or in any part of this study, and I may withdraw at any time, without prejudice to my relations with San Jose State University and the Skilled Nursing Facility at which I am employed.

7) I have received a copy of this consent form for my file.

I HAVE MADE A DECISION WHETHER OR NOT TO PARTICIPATE. MY SIGNATURE INDICAI'ES THAT I HAVE READ THE INFORMATION

PROVIDED ABOVE AND THAT I HAVE DECIDED TO PARTICIPATE.

Date:

Subject's Signature:

Investigator's Signature: 


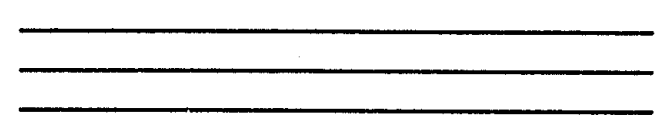

September 7, 1988

To whom It May Concern:

agrees to allow Father Michael Reuss von Plauen, O.S.J., R.N., Ph.D. to conduct his thesis research and inservice testing with our CNAs. The topics to be provided are on AIDS and Universal Precautions.

Due to the sensitivity of this issue, Father Michael has agreed to maintain the confidentiality of the name of the facility from his thesis.

We are happy to assist Father Michael who served in the capacity of Director of Inservice, here, for over four years.

sincerely,

Administrator 
September 7, 1988

To Whom It May Concern:

This letter is to certify that

Hospital

has agreed to participate in the Inservice-Research project of Father Michael Reuss von plauen, on the topics of AIDS and Universal Infection Control Precautions.

On behalf of the owner-administrator, R.N., we welcome the return of Father Michael and his inservice talents.

If I can be of any further assistance, please contact me. Sincerely,

Administrative Assistant 
APPENDIX B

Outline of Presentation 
Outline of Presentation

Effectiveness of an AIDS and Universal Infection Control Precautions Program for Certified Nursing Assistants

Topic: AIDS and the use of Universal Infection Control Precautions

Subject: CNAs

Objectives: At the conclusion of this session, the staff

CNAs will be able to:

1. explain what AIDS is.

2. identify the signs and symptoms of AIDS, in the early and late stages.

3. explain how AIDS is contracted.

4. describe the present treatment modalities for AIDS.

5. restate the steps involved in universal precautions involved in blood and body fluids of their patients.

6. describe how fear can interfere with their relationships with patients.

Teaching Methods:
1. Lecture
2. Discussion
3. Handouts 
Course Content:

1. the disease called AIDS

2. signs and symptoms of AIDS, in the early stage and late stages

3. how AIDS is contracted

4. present treatment modalities for AIDS

5. universal precautions for blood and body fluids

6. how fear can interfere in relationships with patients

Resources :

1. Literature

2. Nursing Care Planning Guides

3. Guide for Health Professionals

Evaluation:

1. Discussion

2. Pretest and Posttest 
APPENDIX C

Pretest and Posttest 
Pretest and Posttest

\section{General Directions:}

Please answer all questions. Thank you for your cooperation. 


\section{AIDS AND UNIVERSAL PRECAUTIONS TEST}

T. = True F. = False

1. Take all blood and body fluid precautions only with patients who have a diagnosis of AIDS.

T. $\mathbf{F} \cdot$

2. HIV transmission to health care workers is extremely rare.

T. F.

3. Thorough hand washing remains the best single safeguard against spreading infections.

T. F.

4. The AIDS virus attacks and destroys the immune system of the patient.

$\mathbf{T}$. F.

5. You can get AIDS from the AIDS patient's saliva, sweat, tears, urine and bowel movement matters.

T. F.

6. Do not give direct patient care or handle patient care equipment if you have an open skin lesion or weeping dermatitis.

T.

F.

7. AIDS patients need meticulous skin care. T. F. 
8. Malnutrition, chronic diarrhea and genital and anal lesions can all contribute to skin breakdown in AIDS patients. T. F.

9. If you use good handwashing techniques, you do not need to use gloves when touching blood and body fluids. T. F.

10. Pregnant health care workers are known to be at a greater risk of contracting HIV infection than nonpregnant CNAs.

T. F.

11. You can not get AIDS from the patients' contaminated clothes and bedding.

T. F.

12. There is a cure for AIDS.

T. F.

13. You can tell by looking that someone has the AIDS virus. T. F.

14. Patients have gotten AIDS through contaminated blood (transfusions) which they received during their previous operations. T. F. F.

15. You cannot get the AIDS virus through everyday contact with people who have AIDS.

T. F. 
16. If you are not in a "high risk group," you do not need to be concerned about getting AIDS.

T. F.

17. Patients with AIDS should be treated in a similar manner as any patient on blood and body secretion precautions. T. F.

18. AIDS patients always need to be placed in a private hospital room.

T. F.

19. No special care needs to be taken with the meal trays used by AIDS patients.

T. F.

20. If you need to clean up a spill involving blood or body fluids of any patient, you can use a household-based bleach solution of 1:10 proportions.

T. F.

21. Gloves need not be worn for handling items or cleaning surfaces soiled with blood or body fluids.

T. F.

22. Gloves need not be worn when bathing a patient with open skin lesions.

T. F. 
23. When a staff member has a cold or similar symptoms, he or she should request a mask to be worn when entering the AIDS patients' room and should tell the patient why you are wearing the mask.

T. F.

24. Gloves should be worn when taking care of an AIDS patient who is incontinent of bowel and/or bladder. T. F.

25. Gloves should be worn for touching blood and body fluids, mucous membranes and non-intact skin of all patients.

T. $\quad$ F.

Thank you for your participation. 
APPENDIX D

Demographic Information 


\section{DEMCGRAPHIC INFORMATION}

This information is strictly confidential, and the information will be used only for statistical purposes for evaluating the effectiveness of this Inservice program.

Sex: $M$

Age: $20-30$

$31-40$

41-50

$51-60$

61 and above

Marital Status:

$$
\begin{aligned}
& \text { Single: } \\
& \text { (with children) } \\
& \text { Married: } \\
& \text { (with children) } \\
& \text { Divorced: } \\
& \text { (with children) } \\
& \text { Significant Relationship: }
\end{aligned}
$$

Ethnicity:

Black:

Hispanic:

Indian (from India):

White:

Asian: 
Years of Education:

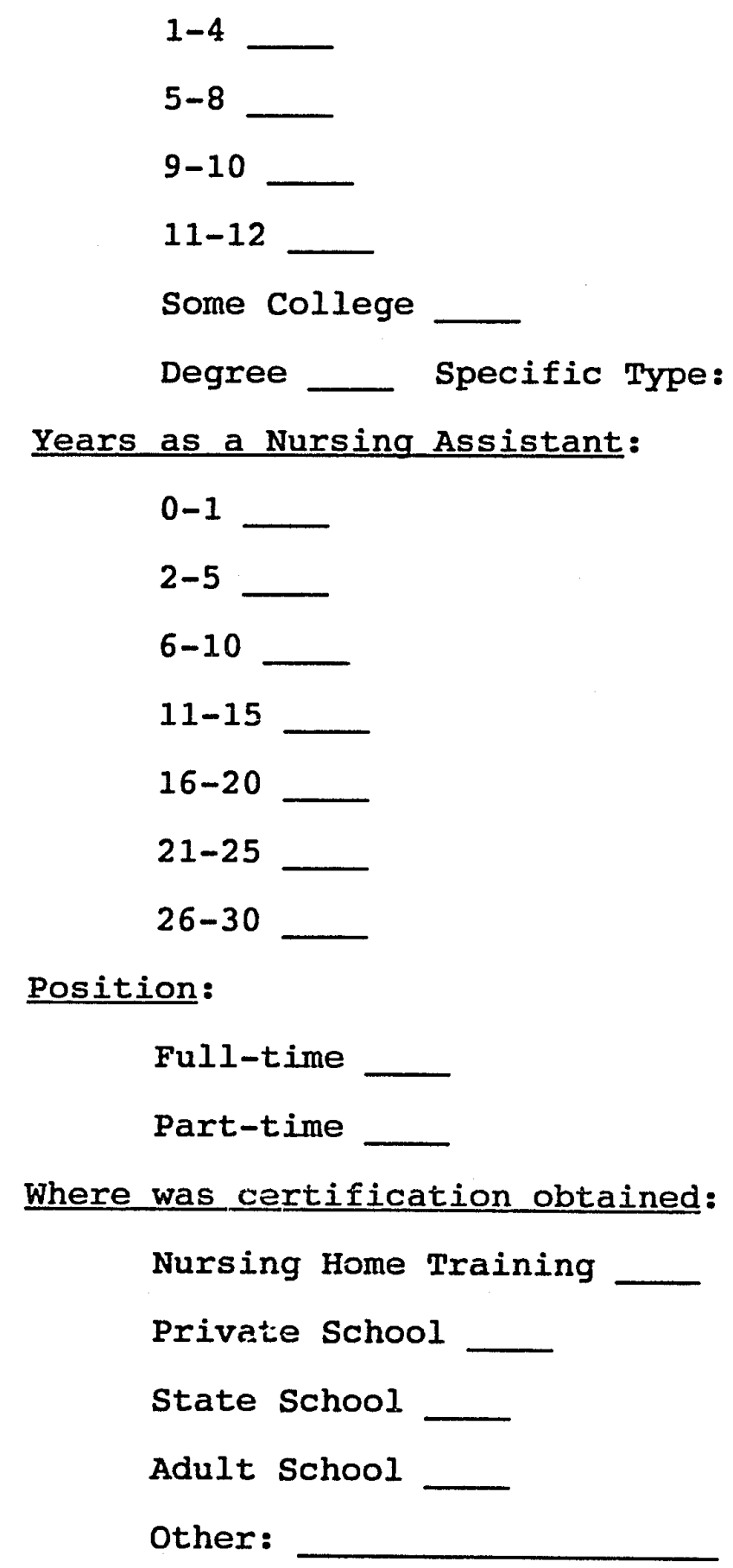


APPENDIX E

Educational Requirements

Title 22, California Administrative Code, 1988, Chapter 3 
Educational Requirements for Certified Nursing Assistants as Specified by Title 22 California Administrative Code, 1988, Chapter 3

1. Role and responsibility as a health team member i 8 hours ) •

2. Principles of safety and infection control (4 hours). 3. Patient care skills (28 hours) which include the following content:

a. communication with patients

b. personal hygiene and comfort measures such as bathing, dressing, oral hygiene, care of hearing aids, prosthesis, personal equipment and belongings, care of incontinent patients, skin care and foley catheter care

c. procedures such as taking vital signs, intake-output recording, specimen collection, application of dry, clean dressings, bowel and bladder management

d. rehabilitation, such as ambulation and range of motion, remotivation

e. physical needs assistance, basic anatomy and physiology understanding, assessing patients and charting

f. nutritional assessment

4. Emotional, social, and spiritual needs of patients ( 10 hours ). 
Subject Content Areas for Certified Nursing Assistant Inservice Pxograms as Specified in Title 22 California Administrative Code, Chapter 3

1. Working with patients who have special problems, such as blindness, deafness, confusion, or communication disability.

2. Bladder and bowel management.

3. Signs and symptoms of probable causes of patients" distress, and emergency procedures, CPR, and relief of choking.

4. Psychosocial aspects of aging and/or chronic illness as they are relevant to the individual, family, and community.

5. Patient care elements including planning and organizing work while giving individualized patient care.

6. Nursing care relevant to body system, including, but not limited to, fracture, diabetes, cardiac disorders, brain syndrome, cerebrovascular accidents, arthritis, and pulmonary disorders.

7. Nutritional needs.

8. Patient care conferences and patient care plans involving the patient and the patient's family, when appropriate. 